\title{
"NONEQUILIBRIUM SULFUR CAPTURE \& RETENTION IN AN AIR COOLED SLAGGING COAL COMBUSTOR
}

\section{Tenth to Thirteenth Quarterly Technical Progress Report}

DOE Contract No:: DE-AC22-95PC95102--10

Contract Period of Performance: 9/14/95 to 3/31/99

Period Covered by Report: January 1,1998 to December 31,1998

Contractor: Coal Tech Corp.

P.O. Box 154, Merion Station, PA 19066

Principal Investigator: Dr. Bert Zauderer， Phone No.(610) 667-0442

Date Submitted: March 15, 1999

\section{Prepared for}

FETC Project Manager: Arun Bose

Federal Energy Technology Center

U.S. Department of Energy

P.O. Box 10940

Pittsburgh, PA 15236 


\section{ABSTRACT}

Calcium oxide injected in a slagging combustor reacts with the sulfur from coal combustion to form sulfur-bearing particles. They are deposited on the liquid slag layer on the combustor wall. Due to the low solubility of sulfur in slag, slag must be rapidly drained from the combustor to limit sulfur gas re-evolution. Analysis indicated that slag mass flow rates in excess of $400 \mathrm{lb} / \mathrm{hr}$ should limit sulfur re-evolution. The objective of this 42 -month project was to perform a series of tests to determine the factors that control the retention of the sulfur in the slag. 36 days of testing on the combustor were completed prior to the end of this reporting period, 12/31/98. This compares with 16 tests required in the original project plan. Combustor tests in early 1997 with high $(37 \%)$ ash, Indian coal confirmed that high slag mass flow rates of about $500 \mathrm{lb} / \mathrm{hr}$ resulted in retention in the slag of up to $20 \%$ of the injected sulfur content mineral matter.

To further increase the slag flow rate, rice husks, which contain $20 \%$ ash, and rice husk char, which contain $70 \%$ ash, were co-fired with coal in the combustor. A series of 13 combustor tests were performed in fourth quarter of 1997 and a further 6 tests were performed in January 1998 and in the summer of 1998. The test objective was to achieve slag flow rates between 500 and $1,000 \mathrm{lb} / \mathrm{hr}$. Due to the very low bulk density of rice husk, compared to pulverized coal, almost the entire test effort focussed on developing methods for feeding the rice husks into combustor. In the last test of December 1997, a peak mineral matter, injection rate of $592 \mathrm{lb} / \mathrm{hr}$ was briefly achieved by injection of coal, rice husk char, gypsum, and limestone into the combustor. However, no significant sulfur concentration was measured in the slag removed from the combustor. The peak injection rate reached with biomass in the 1997 tests was $310 \mathrm{lb} / \mathrm{hr}$ with rice husk, and $584 \mathrm{lb} / \mathrm{hr}$ with rice husk char.

In view of the promising biomass feed rate results, four brief combustor tests were undertaken in January 1998. The combination of cold weather operation and the complexity of coordinating coal, biomass, and sorbent injection prevented the achievement of steady state slag flow conditions in the combustor in the January tests. The next two tests on the combustor were performed in June 1998 with biomass and coal co-firing. Steady state flag flow was not achieved due to the brief operating period.

Due to the high cost of operating the combustor, the period between May and August was devoted to ancillary issues that impact the combustor's operation with biomass. Various means of feeding biomass into the combustor were tested, development began on a novel, pilot scale, biomass gasifier, and a $150 \mathrm{hp}$ gas turbine was placed in operation. The gas turbine's compressed air output would allow rice husk feed rates in excess $2000 \mathrm{lb} /$ hour into the combustor and gasifier. When terminated in August, due to exhaustion of funds, a rice husk feed rate of 1,500 lb/hr into the combustor had been achieved without the compressed air output from the gas turbine. This is a very significant achievement because it means that the combustor can be fired with biomass fuel with little or no co-firing of coal, oil, or gas.

In conclusion, as of the end of August, the procedures had been developed for producing slag flow rates as high as $1,000 \mathrm{lb} / \mathrm{hr}$. This would allow the final determination of the feasibility of encapsulating sulfur in slag in the combustor. Thus while $20 \%$ sulfur reported to the slag in the 
Indian coal tests, which was double the previously measured sulfur concentration in slag was measured in this project, the ultimate potential of sulfur retention in slag requires further testing.

In September 1998, Coal Tech was presented with the opportunity to fire an extremely high (70\%) ash coal from a coal washing plant in the combustor. Efforts to implement these tests are underway at the time of this report, and it is possible that such combustor tests will be implemented in the summer of 1999. These tests would be operated under the very high slag flow rates, in excess of $1000 \mathrm{lb} / \mathrm{hr}$, needed to fully verify the sulfur in slag concept.

In addition, the successful operation of the combustor with biomass, with and without coal cofiring, allows application of this technology to greenhouse gas reduction with biomass fuels. Coal Tech exploring means of bringing this biomass technology to commercial use in the US and overseas. 
'This report was prepared as an account of work sponsored by an agency of the United States Government. Neither the United States Government nor any agency thereof, nor any of their employees, makes any warranty, express or implied, or assumes any legal liability or responsibility for the accuracy, completeness, or usefulness of any information, apparatus, product, or process disclosed, or represents that its use would not infringe privately owned rights. Reference herein to any specific commercial product, process, or service by trade name, trademark, manufacturer, or otherwise does not necessarily constitute or imply its endorsement, recommendation, or favoring by the United States Government or any agency thereof. The views and opinions of authors expressed herein do not necessarily state or reflect those of the United States Government or any agency thereof." 


\section{TABLE OF CONTENTS}

ABSTRACT

1. EXECUTIVE SUMMARY

2. RESULTS AND DISCUSSION

2.1 PROJECT DESCRIPTION

2.1.1. Objectives

2.1.2. Technical Approach

2.1.2.1. Overview of the Work

2.1.2.2. Task Description

2.2. PROJECT STATUS

2.2.1. Effort of the Present Quarter

3. CONCLUSIONS

3.1. EFFORT OF THE NEXT QUARTER
PAGE

ii

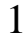

3

3

3

3

3

4

7

7

11

12 


\section{EXECUTIVE SUMMARY}

The objective of this 42 month project was to determine the degree of sulfur retention in slag in a full scale cyclone coal combustor with sulfur capture by calcium oxide sorbent injection into the combustor. The sulfur capture process consists of two steps: Capture of sulfur with calcined calcium oxide followed by impact of the reacted sulfur-calcium particles on the liquid slag lining the combustor. The sulfur bearing slag must be removed within several minutes from the combustor to prevent re-evolution of the sulfur from the slag. To accomplish this requires slag mass flow rates in the range of several $100 \mathrm{lb} / \mathrm{hr}$, and preferably over $400 \mathrm{lb} / \mathrm{hr}$. To study this two step process in the combustor, two groups of tests were implemented. In the first group, calcium sulfate in the form of gypsum, or plaster of Paris, was injected in the combustor to determine sulfur evolution from slag. In the second group, the entire process was tested with limestone and/or calcium hydrate injected into the combustor.

The original planned effort was to consist of a series of up to 16 parametric tests in a 20 MMBtu/hr slagging, air-cooled, cyclone combustor. These 16 tests were completed by June 30, 1997. High slag flow rates were achieved on several tests with a high ash (37\%) Indian coal. In one of the Indian coal tests, a record $20 \%$ of the sulfur injected in the form of gypsum was retained in the slag. This was double the concentration measured in a decade of prior tests in the $20 \mathrm{MMBtu} / \mathrm{hr}$ combustor. However, a subsequent test with the last remaining Indian coal yielded only 5.8\% sulfur in the slag. One explanation for the lower sulfur content was the limited test duration which prevented reaching steady state slag flow conditions in the combustor.

Attempts to secure a source of very high ash $(>30 \%)$ coal in the $3^{\text {rd }}$ quarter of 1997 were not successful. The focus then shifted on co-firing conventional bituminous coal was a high ash biomass, namely rice husk. It has a high $15 \%$ to $20 \%$ ash concentration and a higher heating value (HHV) of 6,500 Btu/lb. To further increase the slag flow rate, rice husk char-ash was secured. It consists of $70 \%$ ash, $30 \%$ carbon, with a HHV of 3,800 Btu/lb. A total of 13 test days were implemented with the rice husks between October and December 1997. A peak mineral injection rate of $592 \mathrm{lb} / \mathrm{hr}$ was briefly achieved. No significant sulfur was measured in the slag, which may have again been due to the lack of steady state slag flow in the brief test period. .

No additional combustor tests were originally planned for 1998. However, in view of the promising results with rice husk biomass in the last quarter of 1997, four brief combustor tests were undertaken in January 1998. Also brief cold flow biomass feed tests were performed in which feed rates as high as $800 \mathrm{lb} / / \mathrm{hr}$ was achieved. However, the combination of operating in cold weather and the complexity of coordinating coal, biomass, and sorbent injection prevented the achievement of steady state slag flow conditions in the combustor.

The next combustor tests were performed in July 1998. Tow brief biomass and coal cofiring tests were performed. Here again, steady state flag flow was not achieved in the brief operating period.

Due to the high cost of operating the combustor, the period between May and August was devoted to testing various means of feeding biomass into the combustor, to development of a 
novel, pilot scale, biomass gasifier, and to operating a $150 \mathrm{hp}$ gas turbine. The compressed air output of the gas turbine was to be used for achieving over $2000 \mathrm{lb} /$ hour pneumatic feeding of biomass into the combustor and gasifier. When terminated in August, a rice husk feed rate of $1,500 \mathrm{lb} / \mathrm{hr}$ into the combustor had been achieved, without the compressed air output from the gas turbine. This is a very significant achievement because the pneumatic feed system had been designed for a maximum of $2,000 \mathrm{lb} / \mathrm{hr}$ of coal feeding. Rice husk has a bulk density that is $1 / 5$ that of coal. Therefore, a peak rate of only $400 \mathrm{lb} / \mathrm{hr}$ had been originally anticipated. Also, the operational procedures for the gasifier and the gas turbine were resolved by the time the test effort ceased at the end of August.

The significant accomplishments of this project are:

- Implementation of 36 combustor tests versus the originally planned 16, all within the original resource allocation.

- Achievement of $20 \%$ sulfur retention in slag in the high (37\%) ash Indian coal.

- Successful co-firing of coal with rice husk biomass under slag flow conditions suitable for high sulfur retention in slag.

- Implementation of the sulfur in slag retention tests under conditions duplicating commercial slagging combustor operation.

- Determination that high slag mass flow rates are a necessary, but not sufficient, requirement for high sulfur retention in slag. The different levels of sulfur retention measured in the high ash, Indian coal and the high ash, co-fired, coal-biomass is one indication of the existence of other factors. In the absence of further data, the low sulfur retention is currently attributed to the lack of steady state operation during the brief test periods (about 1 hour) in the high coal ash and high biomass ash tests.

In conclusion, as of the end of August, the procedures were in place for implementing slag flow tests at rates as high as $1,000 \mathrm{lb} / \mathrm{hr}$ by co-firing rice husk char with coal. Implementation of these high slag flow tests would provide the final determination of the feasibility of encapsulating sulfur in slag in the combustor. Thus, while the $20 \%$ sulfur content measured in the slag during one Indian coal tests was double the previously measured sulfur concentration in slag, the ultimate potential of sulfur retention in slag requires further testing.

In September 1998, Coal Tech proposed to fire an extremely high (70\%) ash coal from a coal washing plant in the combustor. Efforts in this direction are still underway at the time of this report, and it is possible that such combustor tests will be implemented in the summer of 1999. These tests would be operated under the very high slag flow rates needed to fully verify the sulfur in slag concept.

In addition, the successful operation of the combustor with biomass, with and without coal co-firing has opened the applying this technology to greenhouse reducing biomass fuels. A substantial amount of this work was performed with internal Coal Tech resources, and the Company is exploring means of bringing this biomass technology to commercial use in the US and overseas. 


\section{RESULTS AND DISCUSSION}

\subsection{PROJECT DESCRIPTION}

\subsubsection{Objectives}

The primary project objective is to determine the degree of sulfur retention in slag in a full scale cyclone coal combustor. This non-equilibrium process is a key step in the capture and retention of sulfur released during coal combustion by the interaction with calcium based sorbent particles. By encapsulating the sulfur bearing calcium particles in slag, the need for landfilling of this waste is eliminated. This objective was to be implemented through a series of 16 one day tests carried out in a $20 \mathrm{MMBtu} / \mathrm{hr}$ air cooled, slagging combustor-boiler installation located in Philadelphia, PA. The project consists of two tasks. Task 1 consists of the experiments conducted in the $20 \mathrm{MMBtu} / \mathrm{hr}$ combustor, and task 2 consists of analysis of this data. All the operating procedures for this effort have been developed in the 10 years of operation of two designs of this combustor.

\subsubsection{Technical Approach}

\subsubsection{Overview of the Work}

The work of this project is being implemented on Coal Tech's patented, $20 \mathrm{MMBtu} / \mathrm{hr}$, air cooled cyclone coal combustor that is installed on an oil designed, package boiler at a new facility at the Arsenal Business Center in Philadelphia, PA. This new facility consists of a refurbished and upgraded $20 \mathrm{MMBtu} / \mathrm{hr}$ combustor that had been tested at a manufacturing plant in Williamsport, PA from 1987 through 1993. The primary fuel has been, and will remain, coal. Other tests, including combustion of refuse derived fuels and vitrification of fly ash, have been successfully

performed. It had originally been planned to add fly ash injection to achieve high sulfur retention in the slag in the present combustor tests. However, this option was eliminated because the bulk of the fly ash whose mean diameter is less than 10 microns is blown out of the combustor. Instead late in the project, very high (37\%) ash Indian coal and more recently, high ash biomass were used to achieve high slag flow rates.

The combustor's novel features are air-cooling and internal control of $\mathrm{SO}_{2}, \mathrm{NO}_{\mathrm{x}}$, and particulates. Air cooling, which regenerates the heat losses in the combustor, results in a higher efficiency and more compact combustor than similar water-cooled combustors. Internal control of pollutants is accomplished by creating a high swirl in the combustor. This traps most of the mineral matter injected in the combustor and converts it to a liquid slag that is removed from the floor of the combustor.

$\mathrm{SO}_{2}$ is controlled by injecting calcium oxide based sorbents into the combustor to react with sulfur emitted during combustion. The spent sorbent is dissolved in the slag and removed with it, thereby encapsulating the sulfur in slag. Part of the sorbent exits the combustor with the combustion products into the boiler where it can react with the sulfur. The primary objective of 
the present tests is to maximize the degree of sulfur retention in the slag. All spent sorbent not reporting to the slag is either deposited in the boiler or it is removed in the stack particle scrubber.

$\mathrm{NO}_{\mathrm{x}}$ is controlled by staged, fuel rich combustion inside the combustor. Additional reductions have been achieved by Coal Tech using post-combustion sorbent injection.

Excellent progress had been made prior to the start of the present project in meeting several of these combustor performance objectives. One of the most important objectives of this technology development effort is to demonstrate very high $\mathrm{SO}_{2}$ reduction in the combustor. Prior to the start of the present project, the peak $\mathrm{SO}_{2}$ reduction achieved with sorbent injection in the combustor had been $90 \%$. Of this amount a maximum of $11 \%$ of the total coal sulfur was trapped in the slag. Evaluation of this prior data indicated that the low sulfur retention in the slag was due to excessive slag residence time in the combustor. Since the solubility of sulfur in slag is low, long slag residence times (in excess of 5 minutes) can result in substantial sulfur gas re-evolution into the gas phase.

To reduce the slag residence time in the combustor in the present project tests, the slag mass flow rate must be increased to over $400 \mathrm{lb} / \mathrm{hr}$ by either using very high ash coals or by injection coal ash with the coal. High ash mass flow rates increase the slag flow rate.

In order to determine the non-equilibrium sulfur-slag chemistry, calcium sulfate (anhydrite) was injected into the combustor to vary the slag flow rate inside the combustor and to measure the sulfur gas evolution rate independently of the calcium-sulfur heterogeneous capture reaction. This information was used in subsequent tests to measure the combined sorbent-sulfur capture rate in the gas phase with the sulfur retention rate in the slag inside the combustor.

The 16 tests planned for this project were designed to allow full parametric variation of these sulfur-sorbent capture and sulfur-slag re-evolution reactions. Due to the complexity of these processes additional tests were required and implemented, all within the originally allocated project resources.

\subsubsection{Task Description}

\section{Task 1: Sulfur Chemistry Tests in the Slag of a Cyclone Combustor.}

This task was to consist of four groups of tests designed to validate the sulfur chemistry in slag under non-equilibrium conditions. The tests were designed to validate the chemical and fluid mechanical processes occurring in the capture and retention of sulfur in slag. These reactions are based on prior analytical and experimental work in coal slags and coal like slags, such as steel blast furnace slags. The original plan proposal for a total of 20 one-day tests. However, due to resource limitations, the plan was modified at the beginning of this project to accomplish the project objectives in 16 one day tests. To meet all the parametric test variations, the duration of individual test conditions was reduced. However, the number of tests was increased substantially. As of the end of this project, 36 tests, double the planned 16, have been completed, and most of the technical issues related to achieving high sulfur retention have been identified. 
The original project plan was to perform first a group of six tests. Calcium sulfate as gypsum or plaster of Paris was to be injected into the $20 \mathrm{MMBtu} / \mathrm{hr}$ combustor at a rate that duplicates the complete reaction of sulfur from a $\mathbf{2 \%}$ sulfur coal with calcined calcium oxide particles. While maintaining this sulfur concentration fixed, the total slag mass flow rate was to be increased in discrete steps, with each step remaining fixed for a specific period. The purpose of these tests, and the second group of tests (described in the next paragraph), were to measure sulfur re-evolution from a sulfur based calcium compound at concentrations that duplicate the maximum amount of sulfur that can be captured in the combustor with calcium oxide sorbents.

In the second group of six tests, calcium sulfate was to be injected into the $20 \mathrm{MMBtu} / \mathrm{hr}$ combustor at a rate that duplicates the complete reaction of sulfur from a $4 \%$ sulfur coal with calcined calcium oxide particles. While maintaining this sulfur concentration fixed, the total slag mass flow rate was to be increased in discrete steps, with each step remaining fixed for a specific period.

These two groups of tests were to determine the sulfur retention capability of slag as a function of slag residence time in a commercial scale combustor, namely the unit rated at 20 $\mathrm{MMBtu} / \mathrm{hr}$. In other words, these tests focused only on the sulfur retention in slag. This type of test had been performed briefly in the previous $20 \mathrm{MMBtu} / \mathrm{hr}$ combustor facility in Williamsport, and the results indicated that this is an effective method for studying sulfur retention in slagging cyclone combustors.

As these tests were implemented, it was determined that high calcium sulfate levels in the slag sharply increased the slag viscosity to the point of severely inhibiting slag flow. The nature and number of these tests was modified, as is documented in Project Status Section of these Quarterly Progress reports.

In the third group of four tests, the entire sulfur capture process was to be implemented from the injection of the non-calcined sorbent to its reaction in the combustor and impact and removal with the slag. The slag mass flow rate was to be adjusted to duplicate the optimum slag flow rate determined from the group one tests. These fuel rich and fuel lean tests serve to validate the entire sulfur capture and retention process in the combustor.

In the final group of four one day tests, reacted sorbent collected in the boiler and stack baghouse was to be injected into the combustor at the optimum slag mass flow rate determined from the first two groups of tests. The objective of this test series was to determine the degree of sulfur encapsulation in slag in cases where the magnitude of sulfur capture with injection of sorbent in the combustor is insufficient to meet environmental emission standards.

All the experiments were to be conducted in accordance with the procedures developed in the seven years of testing in Williamsport and in the current tests in Philadelphia on the 20 $\mathrm{MMBtu} / \mathrm{hr}$ combustor.

As the test effort proceeded the test plan was modified to account for the results of prior tests. The final test efforts were focused on operation with very high (over 30\%) ash coal where 
the high slag flow rate favors sulfur retention in slag. The benefit of high ash in the coal to the sulfur retention in slag was verified in the in early 1997 by using a 37\% ash Indian coal. Here $20 \%$ of the injected sulfur was retained in the slag, which was double the previous record level measured by Coal Tech and others. A further test with this coal was implemented in the reporting period ending June 30, 1997. Here the sulfur retention level in the slag was only 5.8\%. The low level may have been due to the short test duration

\section{Task 2: Analysis}

The results of the tests are to be analyzed in this task. Part of the analytical models available for this purpose are two and three dimensional combustion codes for the conditions existing in this combustor, and a code for analyzing slag flow on the walls of the combustor. The results will be compared with prior tests in the present combustor and with laboratory scale data on the sulfur chemistry process in coal and steel slags. 


\subsection{PROJECT STATUS}

\subsubsection{Effort of the Present Quarter}

The implementation of the work on this project involves testing on Coal Tech's 20 MMBtu/hr slagging coal combustor-boiler test facility. A second-generation combustor was installed at a new facility in Philadelphia in 1995 and it became operational at the end of 1995. By the end of December 1998, a total of 119 days of tests were successfully implemented. Of this number, 36 tests were performed for the present project. 6 of these were implemented in the present reporting period, between $1 / 1 / 98$ and 12/31/98. The last test was performed in July 1998, and this completed the tests on this project.

The objective of this project was to determine the degree of sulfur retention in slag in a full scale cyclone coal combustor with sulfur capture by calcium oxide sorbent injection into the combustor. This sulfur capture process consists of two steps: Capture of sulfur with calcined calcium oxide followed by impact of the reacted sulfur-calcium particles on the liquid slag lining the combustor. The sulfur bearing slag must be removed within several minutes from the combustor to prevent re-evolution of the sulfur from the slag. To accomplish this requires slag mass flow rates in the range of at least several $100 \mathrm{lb} / \mathrm{hr}$, preferably over $400 \mathrm{lb} / \mathrm{hr}$, or greater. To study this two step process in the combustor, two groups of tests have been implemented. In the first group, calcium sulfate in the form of gypsum or plaster of Paris was injected in the combustor to determine sulfur evolution from slag. In the second group, the entire process is tested with limestone and/or calcium hydrate injected into the combustor.

In a pair of tests with a high (37\%) ash Indian coal in January 1997, excellent results on sulfur retention were obtained. For the first time in the decade long operation of this combustor, a record $20 \%$ of the injected sulfur was retained in the slag, at slag flow rates above $400 \mathrm{lb} / \mathrm{hr}$. During the subsequent quarter, ending in June 30, 1997, two additional tests with this Indian coal were completed. However, in these latter tests only $5.8 \%$ of the sulfur injected into the combustor as gypsum reported to the slag. This was $1 / 4$ of the sulfur content measured with this Indian coal earlier in the project. No conclusive explanation for this difference was found. However, the test duration was limited to under one hour by the small amount of Indian coal available in the June tests.

Consequently, the focus of the effort in the next quarter, ending in September 30, 1997, was to obtain a source of very high ash $(>30 \%)$ coal. Contacts with a Brazilian and an Indian supplier yielded no response. A source of $30 \%$ ash coal from a Pennsylvania strip mine was found. However, it could not be pulverized due to the high shale content.

Therefore, the focus in the fourth quarter ending 12/31/97 was shifted to co-firing bituminous coal with a high ash (16\% to $20 \%)$ rice husk biomass and a very high (70\%) ash rice husk char from a commercial gasifier. 13 combustion tests with this biomass were completed by the end of 1997. 
The use of biomass required major modifications to the feeding method into the combustor, which was designed for pulverized coal combustion. The coal is in powdered form and its density is about $35 \mathrm{lb} / \mathrm{cu}$.ft. The biomass, in this case rice husks, is in the form of small chips and its bulk density is only $7.5 \mathrm{lb} / \mathrm{cu}$.ft. In addition, tests were performed on co-firing coal with char-ash obtained as a residue from a rice husk gasifier. Its density is also only $15 \mathrm{lb} / \mathrm{cu}$.ft. Since the feed system available for the rice husk had a capacity rating of $1000 \mathrm{lb} / \mathrm{hr}$ for coal, and its rating is determined by the bulk density of the feed material, the capacity with rice husks would be $200 \mathrm{lb} / \mathrm{hr}$. (Note only one-half of the solid feed system was available for the rice husk, as the balance had to be reserved for coal feed.) Rice husks are somewhat unique among biomass materials in that they have a high ash concentration ranging from $15 \%$ to $20 \%$. Coal Tech's supply had a $15 \%$ ash content and a HHV of $6,500 \mathrm{Btu} / \mathrm{lb}$. When co-fired with a $10 \%$ ash coal at a nominal feed rate of $1,000 \mathrm{lb} / \mathrm{hr}, 200 \mathrm{lb} / \mathrm{hr}$ rice husk feed rate would yield only a $130 \mathrm{lb} / \mathrm{hr}$ of ash injection. With the addition of about of a nominal 100 pounds of limestone for slag conditioning, the total injection rate of mineral matter would only be 186 pounds. This is much lower than the minimum desired $400 \mathrm{lb} / \mathrm{hr}$ slag flow rate for high sulfur retention.

Consequently, the bulk of the test effort in the 3 months ending 12/31/97, in January 1998, and in May to August 1998, was devoted to developing methods for increasing the biomass feed rate into the combustor. By using a series of innovative designs and procedures the capacity of the feed system was gradually increased from $200 \mathrm{lb} / \mathrm{hr}$ to $1,500 \mathrm{lb} / \mathrm{hr}$ by the time the test effort was terminated in August 1998. This was accomplished by using the decade long experience acquired at Coal Tech in feeding pulverized coal, limestone, gypsum, and refuse derived fuel. By reusing previously expendable components, the expenditure for materials was kept to a minimum.

Feeding the biomass is complicated by its very low density and by its poor flowing characteristics. Well over a dozen different procedures were tried to increase the feed rate and to maintain a steady feed rate without blockage of the feed system. For this reason, co-firing of the biomass with coal was only initiated after the combustor had reached steady-state operating conditions with coal. Furthermore, since many different biomass-feeding methods were tried, all the biomass tests involved manual control of the biomass feed train. As a result, the period of biomass-coal firing was generally in the range of 1 to 2 hours. Also, in order to limit the high cost of firing the combustor, brief cold flow feed tests were performed in which the rice husks were pneumatically blown into a large collection bag and the maximum feed rate was measured. Using this approach, a feed rate of 1,000 lb/hr was achieved in January 1998.

In January 1998,_four tests of one day and one-half day duration were performed. Note that this time period includes combustor and boiler heatup on oil and gas, initial firing with coal only, co-firing of coal and biomass, and combustor cooldown on oil. For the present project, the $70 \%$ ash rice husk char would have been preferred for all the high slag flow tests. However, they had to be preceded by rice husk firing in order to determine if efficient combustion was attainable at each new higher feed rate.

The four January 1998 tests were Nos. 104 to 108 in the test sequence on the 20 MMBtu/hr combustor facility in Philadelphia. The tests were performed on January 7,8,9, and 27. 
These tests demonstrated the importance of recording all details of test operation. For example, in the test of the $7^{\text {th }}$, the compressor air pressure dropped sharply. However, the last time this had occurred was the previous winter, and it was caused by ice formation in one of the baghouse compressed air lines. Consequently, it was possible to correct this problem during the test without shutdown. The forklift truck, which was needed for the test, did not start. It was noted that the ignition wires had been exposed to rain, and this was also corrected during the test. One defective cooling water circuit was repaired during the test. Finally, a break in the rice feed line resulted in early termination of the test. The feed modification used in this test to increase the rice husk feed rate proved unreliable. The peak feed rate was $410 \mathrm{lb} / \mathrm{hr}$, about the same as in the previous December test.

The test was repeated the next day, with the same resultant peak feed rate. Another modification to the rice husk feed line was made for the next day's test, and the feed rate increased to $530 \mathrm{lb} / \mathrm{hr}$. As noted, in all tests, excellent slag operation was achieved.

These three tests yielded suggestions for further feed rate improvements. However, it became clear with the limited budget and the high cost of each combustor test, a lower cost method of testing the rice husk feed system was needed. A method of testing the feed system was devised that did not require a combustion test. After two weeks of testing, the feed rate was increased to $1,000 \mathrm{lb} / \mathrm{hr}$. This is over 5 times the capacity deduced for this system from coal feeding.

On January 27, the fourth combustor test of the month was performed. A peak steady rice husk feed rate of $800 \mathrm{lb} / \mathrm{hr}$ was achieved. This was a major advance for this project because it opened the way for achieving much higher feed rates by modifications to the combustor inlets.

No combustor testing for this project was performed between February and June. Since biomass was being used in the combustor, it was prudent to try to understand some of its combustion characteristics. Therefore, in the period between May and August, work was implemented, primarily with internal resources, on gasification of rice husk. The effort began with pyrolysis studies in a modified, small electric furnace that Coal Tech had fabricated years earlier for another project. Small samples of rice husk were heated in increments to temperatures of up to about 1300F. The residual char and grab samples of the evolved gas were sent out for analysis of the chemical composition and higher heating values. The task of pyrolizing the rice husk involved substantial trial and error. Consequently, only semi-quantitative results were obtained.

Residual char analyses of its heating value at $1000 \mathrm{~F}$ and $1550 \mathrm{~F}$ indicated that as much as $2 / 3$ of the heat content of the rice husks were gasified. This was deduced from the heat content of residual char. Two grab gas samples taken at $1000 \mathrm{~F}$ and at $1550 \mathrm{~F}$ were sent out for analysis. The gas content was primarily $\mathrm{CO}$ and $\mathrm{CH} 4$. However the total gas volume of these molecules added up to only about $35 \%$. No satisfactory explanation was found, and we concluded that the sampling method was inadequate. 
However, the residual char analysis verified that in excess of $50 \%$ of the energy content of the rice husk had gasified at these low temperatures. This result is in agreement with published reports on biomass pyrolysis. This was the result that we sought to verify. To continue beyond that and exactly determine the composition of the gas would have taken too much time, and work on the furnace was halted.

Since the coal and biomass is fed pneumatically into the combustor, an attempt was made to substantially increase the air transport flow rate for the biomass. The two high-pressure blowers used for coal and sorbent transport were already at maximum operating conditions. Another alternative that we used extensively in the past, namely, renting a diesel-powered compressor is very costly. Also, it is a very inefficient means of providing transport air because its operating pressure is about 10 times too high. In early 1998, we obtained on loan a 40 year old, 150 hp gas turbine that had been used by the US Navy for starting jet planes. Its attractiveness for this project was its very high compressed air output at $30 \mathrm{psig}$, which was more than adequate for very greatly increasing the transport air for the feed system.

Although the jet engine was supposedly operational, and it was possible to turn it over at $10,000 \mathrm{rpm}$, sustained ignition at a normal 42,000 rpm was not possible. Also, considerable effort was expended in assuring protection in case the turbine wheel broke apart during operation. There was no instruction manual for the engine. After a search to locate the manufacturer listed on the nameplate, the PI recalled that there were only two major US companies that manufacture small jet engines. And in fact, the manufacturer had been acquired by Allied Signal. We finally located several individuals that were knowledgeable about this engine series, and learned that the only source of a manual was the US Navy's Logistics Center in Philadelphia, PA. We were able to obtain a copy of the manual with the assistance of DOE's FETC ACO. While waiting for the manual, we figured out how to run the engine. We hooked it up to the biomass feed line. Unfortunately, the engine's compressed air output failed during one of the combustor tests that were performed in July, and the biomass could not be fed into the combustor with the jet engine.

In the first test in July, rice husk char was co-fired coal and gypsum. Gypsum was to simulate sulfur retention in slag. The purpose of the test was to operate at slag mass flow rates up to $1,000 \mathrm{lb} / \mathrm{hr}$. The following test conditions were planned.

Char husks feed rates: $500 \mathrm{lb} / \mathrm{hr}(15 \mathrm{~min}) \& 750 \mathrm{lb} / \mathrm{hr}(15 \mathrm{~min})$ and $1000 \mathrm{lb} / \mathrm{hr}(11 \mathrm{~min})$. Heat Input, Q in=13.2 MMBtu/hr, with propane @ $0.7 \mathrm{MMBtu} / \mathrm{hr} \&$ coal @ $850 \mathrm{lb} / \mathrm{hr}$. Test Condition Case 1) 500\#/hr rice husk char: Total ash $=350 \# / \mathrm{h}$ from rice char, plus $85 \# / \mathrm{h}$ from coal ash, and $133 \# / \mathrm{hr}$ of CaSO4 from gypsum $=560 \# / \mathrm{h}$ total mineral input.

Case 2) 750\#/hr rice husk char: Total ash: $525+77+133=735 \# / \mathrm{h}$

Case 3) 1000 \#/h case: Total ash: $700+77+133=910 \# / \mathrm{hr}$

Test \# 1 Results: Since the combustor has not been operated since January some problems with the coal feeder were experienced. As a result the firing rate was not uniform and the slag flow was not as smooth as in the previous January test. Consequently, while slag samples were obtained, they were not sent out for analysis. 
Test \# 2: Results: The biomass char-ash and coal feed were rearranged to obtain smoother fuel and gypsum flow. The feed test was successful. However we had assumed that there was still over 1 ton of coal left in the storage bin. Only several 100 pounds were left and coal flow ceased after about 15 minutes. It was decided to co-fire the biomass char with oil, which was not effective. However, this part of the test confirmed that the char feed modification was effective for feed rates as high as $600 \mathrm{lb} / \mathrm{hr}$.

By that time, the project resources were basically expended, and the available internal resources that Coal Tech could commit to this project were not adequate to continue with the slag sulfur tests.

In its place, Coal Tech decided to pursue a limited effort on gasifying the rice husks at the low temperatures used in the furnace gasification tests. A small gasifier with a nominal throughput capacity of $1,000 \mathrm{lb} / \mathrm{hr}$ was constructed from surplus components left from earlier projects. In a series of tests, in July and August, various modifications on feeding and gasifying the rice husk biomass were implemented. These brief tests resulted in the development of a conceptual design of a simple gasifier. Indirectly, the tests also resulted in development of a biomass feed design that resulted in injection of $1,5000 \mathrm{lb} / \mathrm{hr}$ of biomass into the cyclone combustor. Therefore, indirectly, the gasifier work was of benefit to future combustor operation with shredded biomass and refuse derived fuels.

By the end of August all test work had to cease due to lack of funds. Coal Tech had been unsuccessful in obtaining support from several proposals to utilize the combustor and gasifier as a means of efficiently burning biomass in a low cost gasification and combustion system.

\section{CONCLUSIONS:}

The project is complete. 36 combustor tests were performed, which is more than double the 16 originally planned. We draw three major conclusions from this test effort:

1) A key project objectives of achieving very high slag flow in the $20 \mathrm{MMBtu} / \mathrm{hr}$ combustor in order to retain sulfur in the slag, was attained with high (37\%) ash Indian coal and with high $(70 \%)$ ash rice husk char. In the Indian coal tests, the slag flow rate exceeded the required minimum slag flow-rate of $400 \mathrm{lb} / \mathrm{hr}$, and $20 \%$ of the injected sulfur reported to the slag. This was double the highest concentration of sulfur measured previously in this combustor. The possibility of achieving even higher slag flow rates in the 500 to $1,000 \mathrm{lb} / \mathrm{hr}$ range was demonstrated at the end of the project in brief tests with rice husk char.

2) The second significant result was the demonstration that physical phenomena needed for sulfur retention were validated under full-scale conditions. Prior laboratory scale tests by others have shown that sulfur can be retained in slag if the liquid slag is quenched within a few minutes. Achieving these slag conditions in a full-scale combustor was very challenging, and a substantial part of the project was devoted to achieving the proper slag flow combustor conditions. This also included finding suitable coals fuels and mineral matter. High ash US bituminous coal, coal fly ash, artificial ash (made from a mixture of alumina, silica, and iron oxide 
powder), imported high ash Indian coal, and finally high ash biomass and biomass char were tested.

3) A most important result of this project was the test work on biomass combustion. This has opened the application of this combustor technology to greenhouse gas reduction. This result is a typical example of scientific progress in which a search for the solution to one problem leads to a new application.

\subsection{EFFORT OF THE NEXT TWO QUARTERS}

In the next two quarters, Coal Tech will prepare the final report. 